\title{
Purification and characterization of a newly serine protease inhibitor from Rhamnus frangula with potential for use as therapeutic drug
}

\author{
Abir Ben Bacha ${ }^{1,2} \cdot$ Ikram Jemel $^{2} \cdot$ Nadine M. S. Moubayed $^{3} \cdot$ Imen Ben Abdelmalek $^{4}$
}

Received: 23 November 2016/Accepted: 2 February 2017/Published online: 8 June 2017

(C) Springer-Verlag Berlin Heidelberg 2017

\begin{abstract}
Protease inhibitors from plants are well known to be potent inhibitors of the growth of bacteria, fungi, and even certain viruses which make them excellent candidates for use as the lead compounds for the development of novel antimicrobial agents for applications in medicine. In this study, Rhamnus frangula was selected as a protease inhibitor source. The maximum recovery of the protease inhibitor against trypsin was recorded in the crude extract made in $0.1 \mathrm{M}$ phosphate buffer $(\mathrm{pH} 7.0)$ and isolated from the mature leaves. Then, the protease inhibitor designated as RfIP1 was purified to homogeneity by Sephadex G50 with an apparent molecular mass of $22.5 \mathrm{kDa}$ and its $\mathrm{N}$-terminal sequence exhibited a high degree of homology with known serine protease inhibitor sequences. The RfIP1 displayed maximal activity at $\mathrm{pH} 7$ and $37^{\circ} \mathrm{C}$. It maintained almost $80 \%$ of its maximal activity through a large $\mathrm{pH}$ range. The thermo-stability of RfIP1 was markedly enhanced by $\mathrm{BSA}, \mathrm{CaCl}_{2}$, and sorbitol, whereas the addition of $\mathrm{Mg}^{2+}, \mathrm{Zn}^{2+}, \mathrm{NaTDC}$, SDS, DTT, and $\beta$-ME significantly promoted inhibitory activity. The protease inhibitor displayed high inhibitory activity toward some
\end{abstract}

Abir Ben Bacha

abirghanouchibenbacha@yahoo.fr

1 Biochemistry Department, Science College, King Saud University, P.O. Box 22452, Riyadh 11495, Saudi Arabia

2 Laboratory of Plant Biotechnology Applied to Crop Improvement, Faculty of Science of Sfax, University of Sfax, 3038 Sfax, Tunisia

3 Botany and Microbiology Department, Science College, King Saud University, P.O. Box 22452, Riyadh 11495, Saudi Arabia

4 Biology Department, College of Science and Arts at Buraidah Qassim University, Qassim, Saudi Arabia known proteases (cathepsin B, chymotrypsin, collagenase, thrombin, and trypsin) that have more importance in pharmaceutical industry and it acted as potent inhibitor of some commercially proteases from Aspergillus oryzae, Bacillus sp, and Bacillus licheniformis. The protease inhibitor also possessed an appreciable antibacterial effect against both Gram-positive and Gram-negative bacteria.

Keywords Rhamnus frangula . Protease inhibitor . Characterization · Purification - Therapeutic proteases

\section{Introduction}

Thanks to their utilization in biotechnological and pharmaceutical industries (Cyran 2002; Ahn et al. 2004; Imada 2005; Robert 2005) as well as their potential as valuable tools for the study of reaction mechanisms and enzyme structures, enzyme inhibitors have recently received greater attention of researchers. Several types of selective and specific protease inhibitors have been purified, characterized, and assessed for their biological potentials. In fact, Serine Protease Inhibitors have received great interest for various applications in biomedicine and biotechnology in addition to its application in protein-protein interaction studies, focused mainly in therapeutics. Recent findings have reported proteolysis control as a pharmacologically efficient tool, using different serine protease inhibitors to treat infectious and systemic diseases. Potentiality and therapeutic efficiency of serine protease inhibitors have been exemplified in treating immune, inflammatory, respiratory diseases, AIDS, cardiovascular, and neurodegenerative disorders (as Alzheimer disease). Therefore, protease inhibitors could be useful in drug design to prevent organisms' propagation that provokes dangerous 
diseases, such as AIDS, cancer, and malaria (Johnson and Pellecchia 2006).

It is well established that protease inhibitors are capable to extend the shelf life of various foods produced, as they can delay their proteolysis by inhibiting the activity of exogenous and endogenous proteases throughout food preservation and processing (Reppond and Babbitt 1993). In plants, protease inhibitors are considered as effective defense tools due to their antinutritional interaction against phytopathogens and insects either via inactivating the hydrolase enzymes or depolarization of plasma membrane of the pathogens thereby inhibiting its growth and invasion (Ryan 1990).

Structurally, protease inhibitors belong to various classes, including cysteine, serine, aspartate, and metallo-proteases based on the active amino acid in the reaction centers. However, serine and cysteine protease inhibitors are the most extensively studied ones in plants. Based on their amino acid sequences, eight classes of plant serine protease inhibitors were reported (Mosolov and Valueva 2005). Among them, protease inhibitor 1, protease inhibitor 2 , and soybean trypsin inhibitor families were well studied (Kim et al. 2009; Meulenbroek et al. 2012). Almost all the previously studied serine protease inhibitors are isolated from Solanaceae, Fabaceae, Euphorbiaceae, Poaceae, and Cucurbitaceae families.

Rhamnus frangula is a tall deciduous shrub in the family Rhamnaceae growing to 6-18 feet high on fissures or slopes in limestone rocks. It is native to northernmost Africa Europe and western Asia (Hänsel and Sticher 2007). Previous studies have demonstrated that crude extract of $R$. frangula has strong antioxidant, antimicrobial, and free radical scavenging activities (Manojlovic et al. 2005; Ştef et al. 2009). Although $R$. frangula has been known as a potential source of various bioactive molecules and one of the most common laxatives, it was not described as a protease inhibitor source so far. In this context, the aim of the present study was to screen different parts of $R$. frangula for protease inhibitors for further evaluation of their inhibitory activity against some commercially and therapeutically important proteases as well as their potential for use as antibacterial agents in both human health and food preservation.

\section{Materials and methods}

\section{Extraction and recovery of protease inhibitor}

Randomly selected barks, fruits, leaves, roots, and seeds of wild growing plants of $R$. frangula were collected in October of 2014 in Riyadh city (Kingdom of Saudi Arabia), washed, air dried at room temperature, and ground.
Extraction was performed by homogenizing $25 \mathrm{~g}$ of each sample in $100 \mathrm{~mL}$ of various solutions $(0.05 \mathrm{M} \mathrm{HCl}, 0.2 \%$ $\mathrm{NaOH}(\mathrm{w} / \mathrm{v}), 15 \% \mathrm{NaCl}(\mathrm{w} / \mathrm{v}), 0.1 \mathrm{M}$ phosphate buffer (pH 7.0), and water. Homogenates were incubated in a rotary shaker at $200 \mathrm{rpm}$ and at room temperature for $4 \mathrm{~h}$, filtered and centrifuged at $12,000 \mathrm{rpm}$ and $4{ }^{\circ} \mathrm{C}$ for $15 \mathrm{~min}$ (Pichare and Kachole 1996). The protease inhibitor activity was then assayed in the resulting soluble crude extracts and the one that support the maximal activity was selected for further studies.

\section{Protease inhibitor assay}

Protease inhibitor assay was performed against trypsin following the Kunitz method (Kunitz 1947). Briefly, $1 \mathrm{~mL}$ aliquot of a suitable dilution of the extract sample was mixed with an equal volume of trypsin (1000 units/mg) and pre-incubated at $37^{\circ} \mathrm{C}$ for $15 \mathrm{~min}$. Then, $2 \mathrm{~mL}$ of $1 \%$ casein was added and the obtained mixture was allowed to stand for $30 \mathrm{~min}$ at $37^{\circ} \mathrm{C}$. Finally, $2.5 \mathrm{~mL}$ of $5 \%$ trichloroacetic acid (TCA) solution was added to stop the reaction. After centrifugation of the reaction mixture $(12,000 \mathrm{rpm}, 15 \mathrm{~min})$, the absorbance was measured at $280 \mathrm{~nm}$. One unit of protease inhibitor activity (PIU) was defined as the decrease by one unit of absorbance at $280 \mathrm{~nm}$ of TCA soluble casein hydrolysis product liberated by the action of trypsin per minute under the standard assay conditions (Kunitz 1947). The protease inhibitor activity was also expressed as inhibition percentage which was determined by comparison with a control experiment for comparative purposes.

\section{Purification of protease inhibitor}

The clear crude extract ( $80 \mathrm{~mL}, 15,000$ PIU) was fractionated by $30-75 \%$ saturation with ammonium sulfate. The precipitate obtained after centrifugation $(12,000 \mathrm{rpm}$, $30 \mathrm{~min}$ ) was solubilized in $10 \mathrm{~mL}$ of phosphate buffer (0.05 M, pH 7). The resulting supernatant (10 mL, 11,700 PIU) was then subjected to fractionation using ethanol (50-90\%). Precipitated proteins which contained about $55 \%$ of the initial amount of the protease inhibitor were resuspended in minimum of buffer phosphate buffer (0.05 M, pH 7), and the obtained supernatant $(7 \mathrm{~mL}$, $8190 \mathrm{PIU})$ was then incubated for $30 \mathrm{~min}$ at $70^{\circ} \mathrm{C}$ and centrifuged for $30 \mathrm{~min}$ at $12,000 \mathrm{rpm}$ and $4{ }^{\circ} \mathrm{C}$.

Finally, the crude inhibitor preparation obtained $(6 \mathrm{~mL}$, 6550 PIU) was applied onto a Sephadex G50 column preequilibrated with sodium acetate buffer $(0.1 \mathrm{M}, \mathrm{NaCl}$ $0.15 \mathrm{M}, \mathrm{pH}$ 5.4). The proteins were eluted using the same buffer at a flow rate of $0.5 \mathrm{~mL} / \mathrm{min}$, and $4 \mathrm{~mL}$ fractions were gathered. The protein elution profile was recorded spectrophotometrically at $280 \mathrm{~nm}$. Fractions containing 
protease inhibitory activity were analyzed electrophoretically by analytical polyacrylamide gel $(15 \%)$ in the presence of sodium dodecyl sulfate (SDS-PAGE), and pure active fractions were then pooled, concentrated, and stored at $4{ }^{\circ} \mathrm{C}$ until used for further biochemical characterization.

\section{Protein analysis}

Protein concentration was performed according to the method of Bradford (Bradford 1976). The purified protease inhibitor was analyzed with $15 \%$ SDS-PAGE following the method of Laemmli (Laemmli 1970). The alkylation of the cysteine residues of the enzyme was performed as described previously (Okazaki et al. 1985). The $\mathrm{NH}_{2}$-terminal sequence was determined by automated Edman's degradation, using an Applied Biosystems Protein Sequencer Procise 492 equipped with 140 C HPLC system (Roissy, France) (Hewick et al. 1981).

\section{Effect of $\mathrm{pH}$ and temperature on the protease inhibitor activity and stability}

Protease inhibitor activity was tested in various buffers at different pHs (3-13) at $37{ }^{\circ} \mathrm{C}$. The substrate casein $(1 \%)$ was prepared in the respective $\mathrm{pH}$ buffers as follows: $200 \mathrm{mM}$ sodium acetate buffer (pH 3-5), $200 \mathrm{mM}$ potassium phosphate buffer (pH 6-7), $200 \mathrm{Mm}$ Tris- $\mathrm{HCl}$ buffer (pH 8-9), and $200 \mathrm{mM}$ glycine-NaOH buffer ( $\mathrm{pH} \mathrm{10-13).}$ The $\mathrm{pH}$ stability of the protease inhibitor was determined by incubating the enzyme at various $\mathrm{pH}$ values ranging from 2 to 13 for $12 \mathrm{~h}$ at $4{ }^{\circ} \mathrm{C}$ using the same buffers. The residual protease inhibitor activity was determined after centrifugation (30 min at 12,000 rpm) under the standard assay method. Each measurement was performed in triplicate.

Furthermore, the optimum temperature of the protease inhibitor activity was determined by carrying out the enzyme assay at different temperatures $\left(20-70{ }^{\circ} \mathrm{C}\right)$ at $\mathrm{pH} 7$. As for the thermal stability, it was studied by incubating the protease inhibitor at $\mathrm{pH} 7$ and at different temperatures $\left(30-90{ }^{\circ} \mathrm{C}\right.$ ) and different time intervals ( $15 \mathrm{~min}, 30 \mathrm{~min}, 1$, $2,3,6,9,12$, and $15 \mathrm{~h}$ ) and measuring the residual activity with time, after centrifugation (30 min at 12,000 rpm), under the standard assay method.

\section{Stabilizers influence on theRfIP1thermo-stability}

The improvement of thermo-stability of the purified protease inhibitor at $80{ }^{\circ} \mathrm{C}$ was also examined by adding several thermal stabilizers, such as BSA (1\%), $\mathrm{CaCl}_{2}$ $(10 \mathrm{mM})$, cysteine hydrochloride $(10 \mathrm{mM})$, glycerol
(10\%), glycine (1 M), PEG 8000 (10 mM), sorbitol (10\%), casein $(1 \%)$, starch $(1 \%)$, sucrose $(1 \%)$, and urea $(10 \mathrm{mM})$. Samples were incubated for $2 \mathrm{~h}$ at $80{ }^{\circ} \mathrm{C}$ and then checked for protease inhibitor activity.

\section{Metal ions influence on the RfIP1 activity}

The influence of metal ions on the protease inhibitor activity was determined by the addition of various divalent ions (such as $\mathrm{Ca}^{2+}, \mathrm{Cd}^{2+}, \mathrm{Co}^{2+}, \mathrm{Fe}^{2+}, \mathrm{Hg}^{2+}, \mathrm{Mg}^{2+}, \mathrm{Mn}^{2+}$, and $\mathrm{Zn}^{2+}$ ) to the reaction mixture at 1 and $10 \mathrm{mM}$ final concentrations. After incubation for $1 \mathrm{~h}$ at $37^{\circ} \mathrm{C}$, the protease inhibitor activity was assayed under optimal conditions.

\section{Effect of reducing and oxidizing agents and surfactants on the RfIP1 activity}

Impact of oxidizing agents [dimethyl sulfoxide and (DMSO), hydrogen peroxide $\left(\mathrm{H}_{2} \mathrm{O}_{2}\right)$, and sodium hypochlorite $(\mathrm{NaOCl})$ at different concentrations ranging from 1 to $5 \%(\mathrm{v} / \mathrm{v})]$ and reducing agents $[\beta$-mercaptoethanol ( $\beta \mathrm{ME})$ and dithiothretol (DTT) at different concentrations ranging from 0.2 to $1 \%(\mathrm{v} / \mathrm{v})$ ] on the protease inhibitor activity was examined by incubating the protease inhibitor with each of these agents for $30 \mathrm{~min}$ and then determining its residual activity. Furthermore, effect of several non-ionic and ionic surfactants, such as NaTDC, SDS, Triton X-100, Tween-80, and Tween-20 on the protease inhibitor activity, was investigated by incubating the protease inhibitor in the presence of each surfactant for $60 \mathrm{~min}$ and estimating its residual activity in the dialyzed mixture against $0.1 \mathrm{M}$ phosphate buffer ( $\mathrm{pH} 7$ ).

\section{Effect of RfIP1on some available important therapeutic proteases}

Influence of the studied protease inhibitor on five available proteases with therapeutic importance, such as Elastase (Sigma-Aldrich, E8140), cathepsin B (Sigma-Aldrich, C6286), chymotrypsin (Sigma-Aldrich, C3142), collagenase (Sigma-Aldrich, C2674), and thrombin (SigmaAldrich, T7513), was evaluated. These enzymes activities were determined according to (Kunitz 1947; Fritz et al. 1966; Barrett 1981; Ian 2001) protocols, respectively. The enzymes' inhibitions in the presence of RfIP1 were performed by adding the inhibitor $(0.25 \mathrm{mg} / \mathrm{mL})$ to the respective reaction mixture, pre-incubating for $15 \mathrm{~min}$, and then measuring the remaining enzyme activity. Protease inhibitor activity of the respective enzyme is expressed in terms of percent inhibition. 
RfIP1 influence on some available commercially proteases

The effect of the studied protease inhibitor on six available commercially proteases activities: esperase (Novozyme, Sigma-Aldrich, P5860), proteinase K (Sigma-Aldrich, P2308), subtilisin (Sigma-Aldrich, P5380), and that obtained from Aspergillus oryzae (Sigma-Aldrich, P6110), Bacillus licheniformis (Sigma-Aldrich, P4860), and Bacillus sp. (Sigma-Aldrich, P3111) was investigated under the same conditions. The inhibitor $(0.25 \mathrm{mg} / \mathrm{mL})$ was added to the respective reaction mixture and pre-incubated for $10 \mathrm{~min}$. Then, the residual enzyme activity was assayed as described elsewhere. Protease inhibitor unit is defined as the amount of protease inhibitor that inhibited one unit of respective enzyme activity. The protease inhibitor activity was also expressed as inhibition percentage which was determined by comparison with a control assay for comparative purposes.

\section{Antibacterial activity of the RfIP1}

The antibacterial activity of the crude extract and the purified protease inhibitor was evaluated against Grampositive, Bacillus cereus (ATCC 14579) and Bacillus subtilis (ATCC 6633), Enterococcus faecalis (ATCC 29122), Staphylococcus aureus (ATCC 25923), Staphylococcus epidermidis (ATCC 14990), and Gram-negative, Salmonella enteric (ATCC 43972), Pseudomonas aeruginosa (ATCC 27853), Klebsiella pneumonia (ATCC 700603), and Escherichia coli (ATCC 25966) strains using the agar diffusion method (Berghe and Vlietinck 1991). The bacterial strains were cultured in a nutrient broth for $24 \mathrm{~h}$. Each bacterial suspension $\left(10^{6} \mathrm{CFU}\right.$, $0.2 \mathrm{~mL}$ ) was spread on Muller Hinton agar, and pores were then loaded with $10 \mu \mathrm{l}$ of the crude extract and the totally purified protease inhibitor $(1 \mathrm{mg} / \mathrm{mL})$. The plates were incubated overnight at $37^{\circ} \mathrm{C}$. Acetate buffer was used as the negative control, and ampicillin $(10 \mu \mathrm{g} / \mathrm{well})$ was used as the positive control. The diameter of zone of inhibition (mean of triplicates \pm SD) as indicated by clear area which was devoid of microbial growth was measured.

Bacterial viability was assessed by measuring colonyforming ability of bacteria incubated in the absence or presence of the purified RfIP1 for various times. Mixtures that contained $1 \times 210^{7} \mathrm{CFU} / \mathrm{ml}$ in sterile $\mathrm{BHI}$ and the protease inhibitor at appropriate amount were incubated for $2 \mathrm{~h}$ with shaking at $37^{\circ} \mathrm{C}$. At various time intervals, samples were withdrawn, serially diluted into sterile BHI, streaked onto media agar plates, and incubated $24 \mathrm{~h}$ at $37{ }^{\circ} \mathrm{C}$ to calculate the bacterial viability by colony counting. The bactericidal effect of the purified RfIP1 was expressed as the residual number of $\mathrm{CFU}$ with respect to the starting inoculum and the $\mathrm{IC}_{50} \%$ (concentration eliciting $50 \%$ effect) corresponding to the protease inhibitor concentration capable of killing $50 \%$ of the starting inoculum.

\section{Results and discussion}

\section{Screening for protease inhibitor from different parts of $\boldsymbol{R}$. frangula}

Proteases inhibitors which are of common occurrence in plants are generally small proteins that have mainly found in storage tissues, such as seeds and tubers; however, they also occur in the aerial parts of plants (De Leo et al. 2002). In plants, protease inhibitors are also induced in response to attack by pathogens and insects or injury (Ryan 1990). They act as anti-metabolic proteins causing the inhibition of the digestive process of insects (Lawrence and Koundal 2002).

Bark of Frangula alnus Mill. is widely used as laxative and can be present as constituent of herbal laxative preparations due to the presence of frangulins, glucofrangulins and anthraquinone glycoside derivatives (EMEA 2007; Males and Kremer 2010). Although R. frangula is known as source of various bioactive substances with industrial and pharmaceutical applications (EMEA 2007; Males and Kremer 2010; Kremer and Kosalec 2012), it is never described as a source of any protein inhibitors.

In the present study, it was noted that among the different parts of the $R$. frangula screened, mature leaves (77 $\pm 3.2 \%$ inhibition) showed the highest levels of inhibition against trypsin activity. However, fruits (43 $\pm 5.1 \%$ inhibition), seeds $(25 \pm 4.5 \%$ inhibition), barks (12 $\pm 2.7 \%$ inhibition), and roots ( $\pm 1.5 \%$ inhibition) showed less amount of trypsin inhibitor activity (Fig. 1a). These findings may be explained by the fact that leaves are well known to be the major tissues attacked by pathogens and pest, thereby indicating a tissue specific expression of protease inhibitors. Furthermore, to select the best method for maximal extraction of protease inhibitor from $R$. frangula leaves, various solvents were investigated. As shown in Fig. 1b, the highest protease inhibitor activity was recorded in the crude extract prepared in $0.1 \mathrm{M}$ phosphate buffer (pH 7.6) (86 $\pm 5.1 \%$ inhibition) followed by the one prepared in distilled water $(55 \pm 6.1 \%$ inhibition). Similar results are reported for the maximal extraction of proteins from Moringa oleifera leaves (Bijina et al. 2011) and Cajanus cajan seeds (Pichare and Kachole 1996). Thus, R. frangula leaves which may be a rich source of protease inhibitor were considered for further studies. 

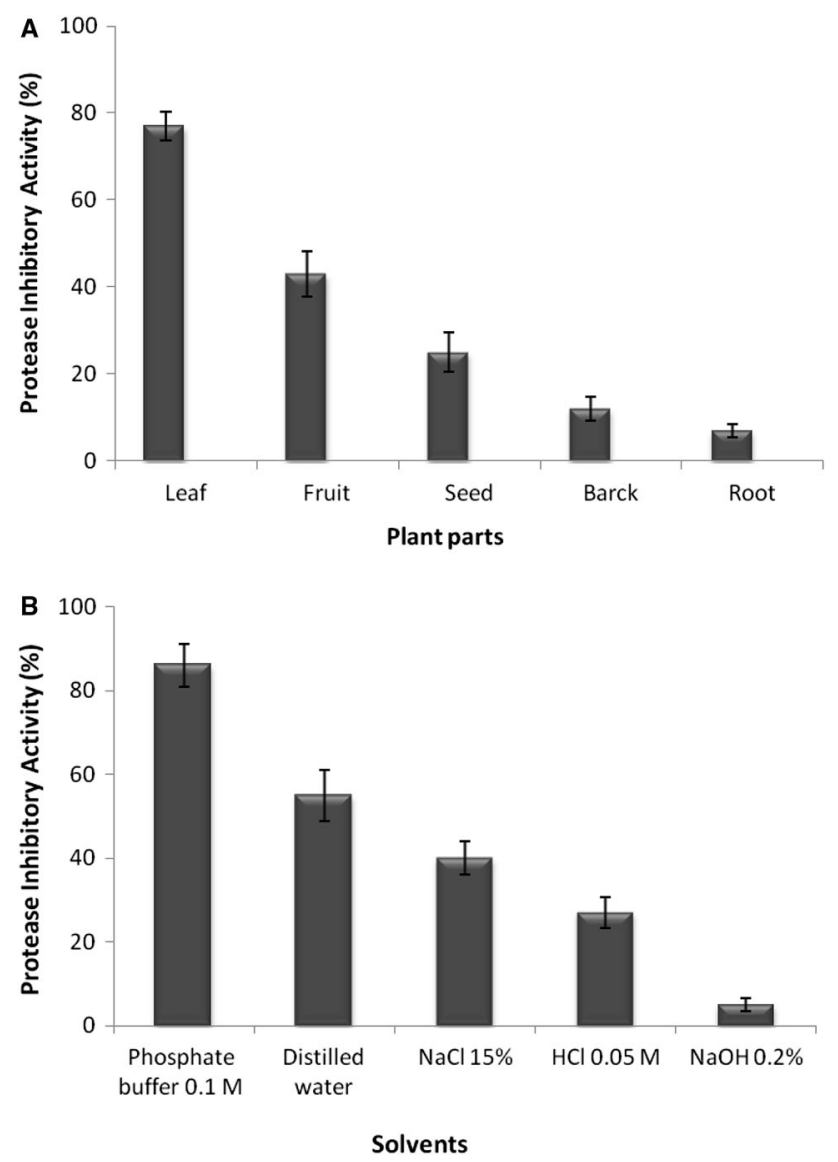

Fig. 1 Screening for protease inhibitor from different parts of $R$. frangula: a distribution of protease inhibitor in different parts of $R$. frangula. b Extraction of protease inhibitor using different solvents. Data shown are mean $\pm \operatorname{SD}(n=3)$

\section{RfIP1 purification}

The protease inhibitor was extracted and purified form $R$. frangula leaves by the three steps procedure detailed in "Materials and methods". The protein elution profile of the final purification step presented in Fig. 2a showed that the protease inhibitor activity emerged in a single peak between 1.4 and 1.7 void volumes (Fig. 2a). The active fractions analyzed on SDS-PAGE (Fig. 2b) clearly showed that the protease inhibitor was homogenously purified and had an apparent molecular mass of about $22.5 \mathrm{kDa}$. This result suggested that the inhibitor protein purified belongs to the Kunitz type of serine protease inhibitor family, whose members are mostly monomeric or dimeric with a molecular mass ranging from 18 to $26 \mathrm{kDa}$ (Kunitz 1947; Macedo et al. 2003).

The purification flow sheet summarized in Table 1 showed that after the Sephadex G-50 gel filtration, a high recovery yield of $25.7 \%$ of the initial protease inhibitor activity and a purification factor of 80 fold were reached with a specific inhibitory activity of $1040.5 \mathrm{PIU} / \mathrm{mg}$.
Interestingly, reduced and alkylated RfIP1 was completely inactive and failed to inhibit trypsin which proves that it is of proteic nature and the protease inhibition is not influenced by other molecules.

The $\mathrm{NH}_{2}$-terminal sequence of the first 33 residues of the purified protease inhibitor was determined (MKSTIFFIFL FCATTTSYLP SLIVDFVLDN NGN) and showed a significant homology degree with those of the Kunitz family reported so far (Kunitz 1947; Creighton and Charles 1987; Jofuku and Goldberg 1989).

\section{Effect of $\mathrm{pH}$ and temperature on the activity and stability of RfIP1}

The effect of $\mathrm{pH}$ on RfIP1 activity and stability is shown in Fig. 3. The result was a bell-shaped curve showing an optimal activity ( $86 \pm 2 \%$ inhibition) at $\mathrm{pH} 7$ (Fig. 3a). The activity was found to decrease gradually at higher and lower $\mathrm{pH}$ ranges. Interestingly, it was noticed that the inhibitor maintained more than $35 \%$ of its activity at extreme $\mathrm{pH}$ conditions. Moreover, the purified protease inhibitor was highly stable at extreme $\mathrm{pH}$ conditions maintaining around $50 \%$ of its inhibitor activity when incubated at $\mathrm{pH} 3$ or $\mathrm{pH} 11$ for $12 \mathrm{~h}$ (Fig. 3b). Several protease inhibitors in the Kunitz family were previously reported to be stable in the alkaline $\mathrm{pH}$, while they are very sensitive to acidic $\mathrm{pH}$ losing their full activity when incubated at $\mathrm{pH}$ values of less than 5 for few minutes (Mello et al. 2002; Bijina et al. 2011). Kridric et al. suggested that the functional stability of Kunitz-type protease inhibitors in the extreme conditions of $\mathrm{pH}$ and temperature and when incubated with reducing agents is probably due to the intra molecular disulphide bridges (Kridric et al. 2002). The stability of the protease inhibitor at a large range of $\mathrm{pH}$ is an encouraging and interesting characteristic that can be exploited in biotechnological and pharmaceutical industries.

The influence of the temperature on protease inhibitor activity was also performed using the standard assay. Obtained result showed that RfIP1 was most active at temperatures from 20 to $50{ }^{\circ} \mathrm{C}$, with a maximal of $86 \pm 3.4 \%$ protease inhibition around $37{ }^{\circ} \mathrm{C}$. However, the protease inhibitor activity decreased of about $50 \%$ above $60{ }^{\circ} \mathrm{C}$ andis completely lost at $70{ }^{\circ} \mathrm{C}$ (5\% inhibition) (Fig. 3c). Similar results were described for almost all plant protease inhibitors of Kunitz type of serine protease inhibitor family (Hamato et al. 1995; Bijina et al. 2011).

The thermal stability profile of RfIP1 indicated that the inhibitor protein retained around $85 \%$ of its full activity when incubated for $30 \mathrm{~min}$ at $70{ }^{\circ} \mathrm{C}$ (Fig. 3d). However, more than $60 \%$ of its inhibitory activity was lost after incubation for only $15 \mathrm{~min}$ at temperature above $80^{\circ} \mathrm{C}$. Such high thermal stability may indicate that the protease 


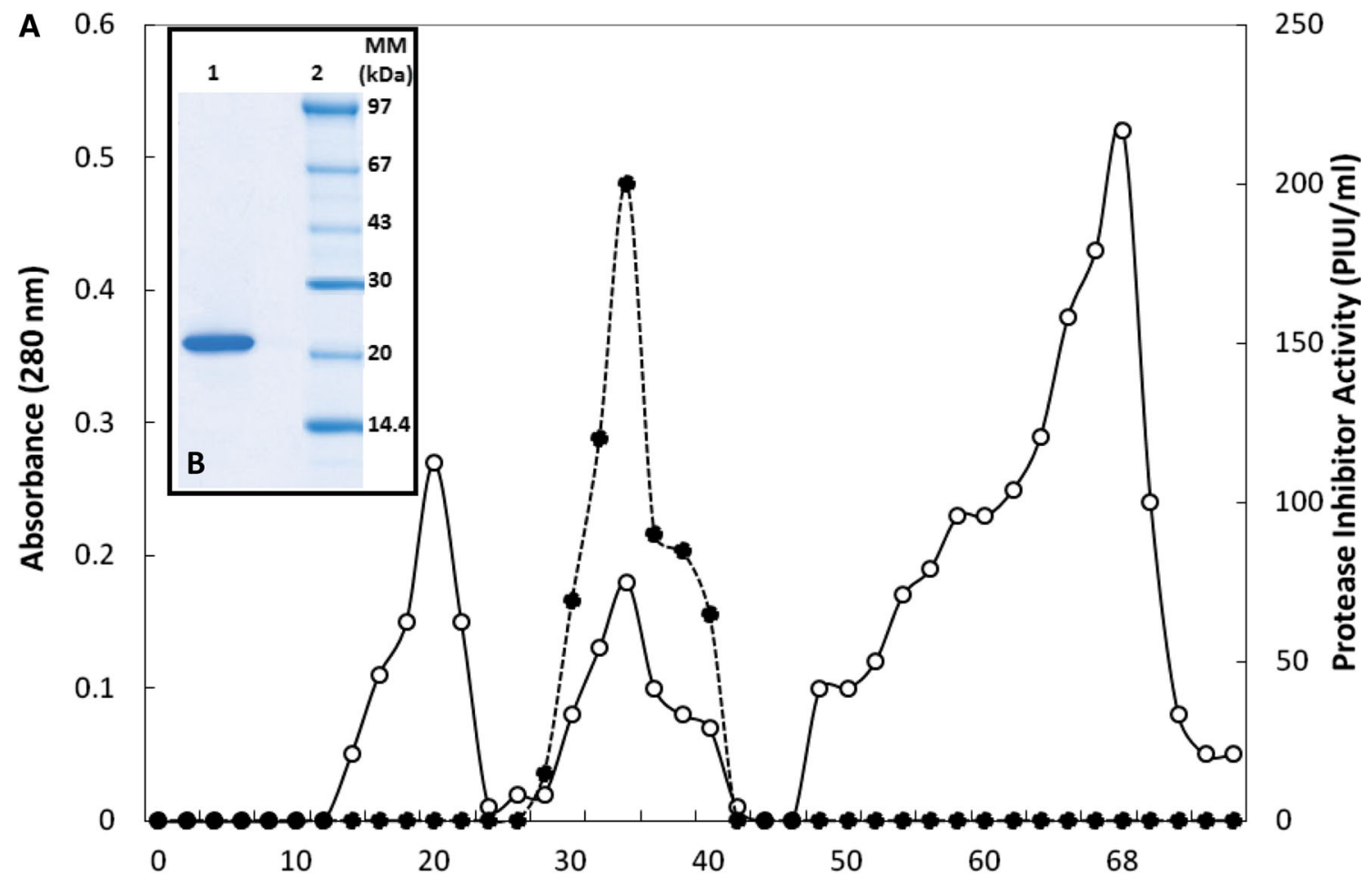

Fraction $\mathrm{n}^{\circ}$

Fig. 2 Purification of $R$. frangula protease inhibitor: a Sepahdex-G50 chromatography of $R$. frangula protease inhibitor. The column $(3 \mathrm{~cm} \times 120 \mathrm{~cm})$ was equilibrated with sodium acetate buffer (0.1 M, NaCl $0.15 \mathrm{M}$ pH 5.4). The proteins were eluted using the same buffer, and fractions (4 mL/fraction) were collected at a flow rate of $0.5 \mathrm{~mL} / \mathrm{min}$. Protease inhibitor activity was measured, as described in "Materials and methods". Active fractions (30-40) were gathered. b SDS-PAGE (15\%) of pure protease inhibitor. Lane 1 $10 \mu \mathrm{g}$ of protease inhibitor eluted from Sepahdex-G50; lane 2 molecular mass markers (Pharmacia). The gel was stained with Coomassie blue to reveal proteins

Table 1 Flow sheet of $R$. frangula protease inhibitor purification

\begin{tabular}{|c|c|c|c|c|c|}
\hline Purification step & $\begin{array}{l}\text { Total activity } \\
\text { (units) }^{\mathrm{a}}\end{array}$ & $\begin{array}{l}\text { Protein } \\
(\mathrm{mg})^{\mathrm{b}}\end{array}$ & $\begin{array}{l}\text { Specific activity } \\
\text { (PIU/mg) }\end{array}$ & $\begin{array}{l}\text { Activity } \\
\text { recovery } \\
(\%)\end{array}$ & $\begin{array}{l}\text { Purification } \\
\text { factor }\end{array}$ \\
\hline Extraction & 15,000 & 1150 & 13 & 100 & 1 \\
\hline Ammonium sulfate fractionation $(30-70 \%)$ & 11,700 & 541 & 21.6 & 78 & 1.6 \\
\hline Ethanol Fractionation (50-90\%) & 8190 & 160 & 51.2 & 54.6 & 3.9 \\
\hline Heat treatment & 6550 & 25 & 262 & 43.7 & 20.1 \\
\hline Sephadex G-50 & 3850 & 3.7 & 1040.5 & 25.7 & 80 \\
\hline
\end{tabular}

a 1 Unit: one unit of protease inhibitor activity was defined as the decrease by one unit of absorbance of TCA soluble casein hydrolysis product liberated by trypsin action at $280 \mathrm{~nm}$ per minute under the assay conditions

b Proteins were estimated using the Bradford method (13). The experiments were conducted three times

inhibitor displays a high intrinsic stability in its native state as it was previously described for all trypsin inhibitor family. Ellenreider et al. have demonstrated that the presence of a protein substance promoted the thermal denaturation of the soybean trypsin inhibitor (Ellenreider et al. 1980). The marked resistance of the purified protease inhibitor against high temperatures can be considered as an interesting and promising property for its possible potential use as therapeutic drug and as seafood preservative.

\section{Stabilizers influence on the RfIP1 thermo-stability}

Thermal stability is the most essential feature for biotechnological application of proteins and its 

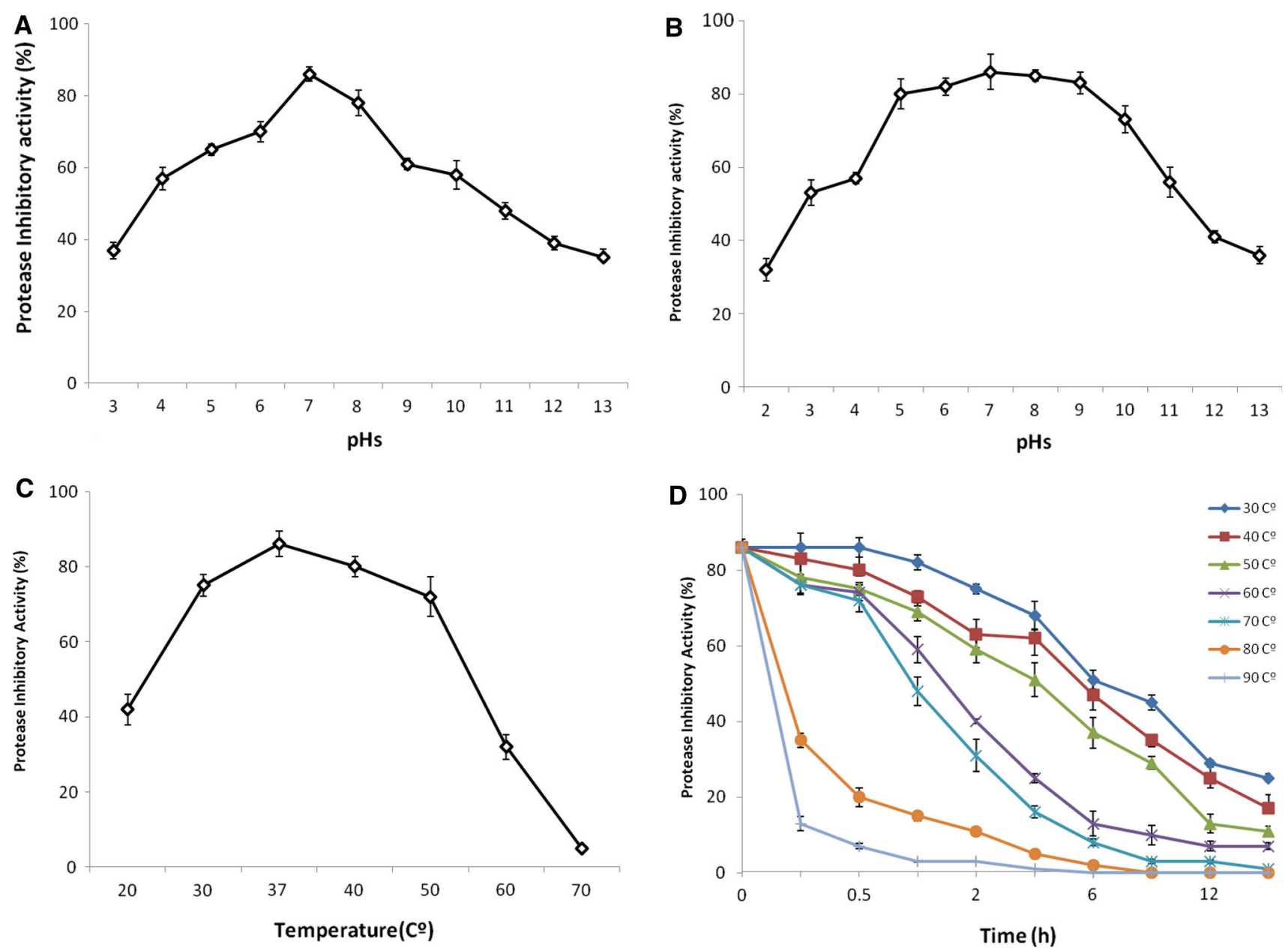

Fig. 3 Effect of $\mathrm{pH}$ and temperature on RfIP1 activity: Effect of $\mathrm{pH}$ on RfIP1 activity (a) and stability (b). Inhibitor activity was assayed at various $\mathrm{pHs}$ against trypsin. For stability studies, the protease inhibitor incubated at different $\mathrm{pHs}$ for $12 \mathrm{~h}$ and assayed for residual inhibitor activity at standard conditions. Effect of temperature on RfIP1 activity (c) and stability (d). Inhibitor activity was assayed at

enhancement is thus desirable to increases its efficiency (Pandhare et al. 2002). In this context, Jamal et al. reported that osmolytes, such as salts, polyols, and amino acids, are capable to stabilize the thermally unfolded proteins and thereby protecting them against thermal inactivation (Jamal et al. 2009).

To advantageously enhance the thermal stability of the purified protease inhibitor at very high temperature, effect of several additives (such as $\mathrm{BSA}, \mathrm{CaCl}_{2}$, casein, cysteine hydrochloride, glycerol, glycine, PEG 8000, sorbitol, starch, sucrose, and urea) as thermal stabilizers of RfIP1 was examined at $80{ }^{\circ} \mathrm{C}$. As we can show in Fig. 4, as compared to the control (in the absence of stabilizer), almost all the tested stabilizers significantly enhanced thermal stability and thus inhibitory activity. At $80^{\circ} \mathrm{C}$, the thermal stability was promoted in the order by $\mathrm{CaCl}_{2}$ $(75 \pm 3.5 \% \quad$ inhibition $)>$ BSA $\quad(65 \pm 2.3 \%$

various temperatures against trypsin. For stability studies, the protease inhibitor incubated at different temperatures and drawn at various time intervals and assayed for residual inhibitor activity at optimal conditions of $\mathrm{pH}$ and temperature. Data shown are mean $\pm \mathrm{SD}$ $(n=3)$

inhibition $)>$ sorbitol $(62 \pm 3.3 \%$ inhibition $)>$ Glycerol $(42 \pm 2 \%$ inhibition $)>$ sucrose and starch $(\sim 36 \%$ inhibition). Glycine and casein ( $\sim 22 \%$ inhibition) moderately enhance the thermal stability of the RfIP 1 at $80{ }^{\circ} \mathrm{C}$, while cysteine hydrochloride, PEG 8000 , and urea did not display any support of the thermal stability of the RfIP1 under the same conditions. The significant amelioration of the thermal stability of the protease inhibitor observed in the presence of $\mathrm{Ca}^{2+}$ ions suggested that these ions may stabilize the inhibitor protein through non-specific and specific binding sites thus preventing the protein unfolding at higher temperatures.

\section{Metal ions influence on the RfIP1 activity}

A wealth of information has been accumulated on the crucial role of metal ions in sustaining the structural

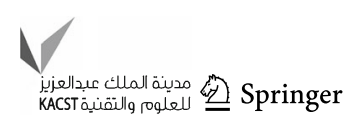


Fig. 4 Effect of stabilizers on RfIP1 activity at $80{ }^{\circ} \mathrm{C}$. The inhibitor activity was determined under the standard assay conditions ( $\mathrm{pH} 7$ and $37{ }^{\circ} \mathrm{C}$ ) after $4 \mathrm{~h}$ of incubation of the inhibitor protein with various thermo-stabilizers. Data are means of triplicate determinations $\pm \mathrm{SD}$
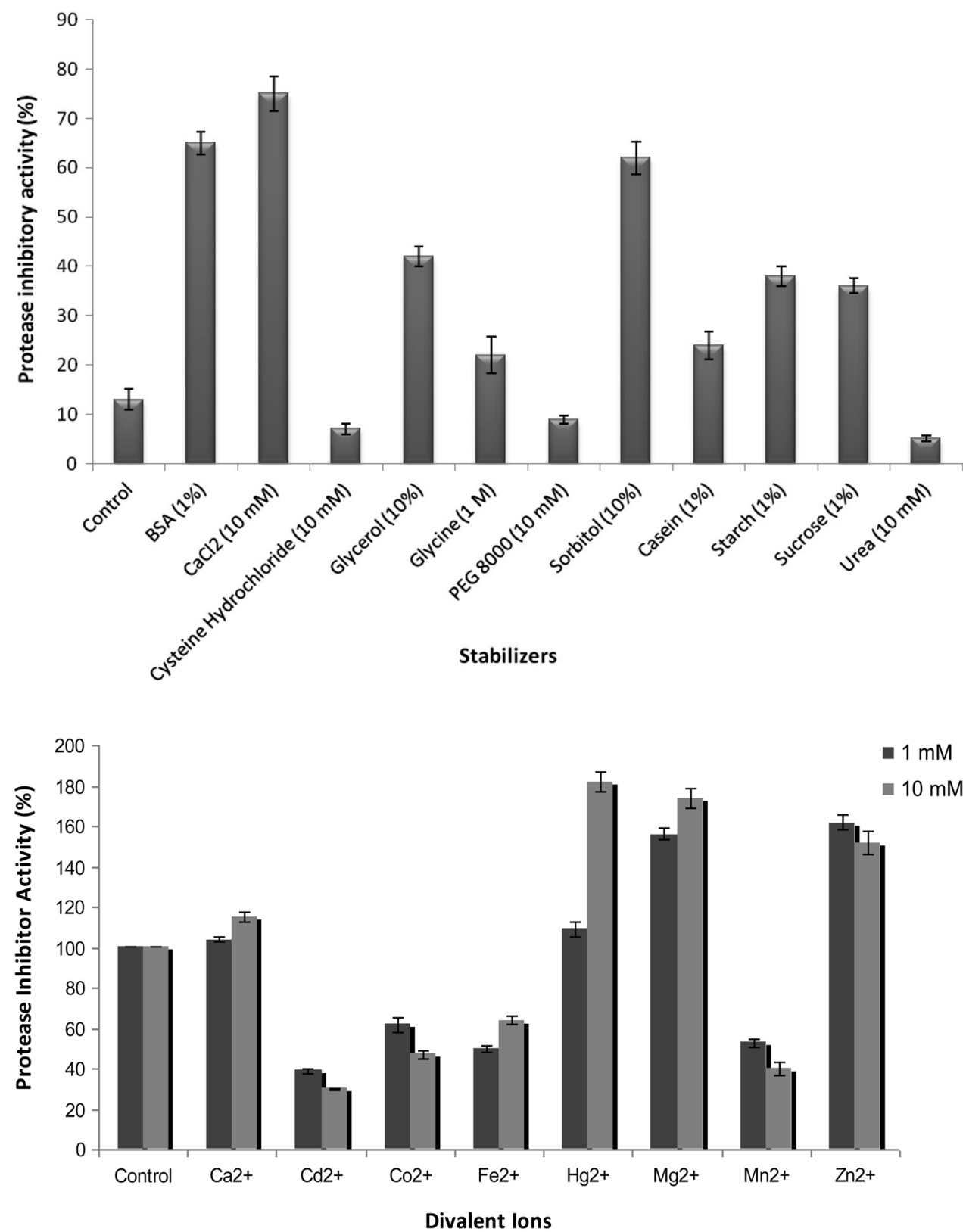

Fig. 5 Effects of different concentrations of metal ions on RfIP1 activity. The protease inhibitor assay was performed at $37{ }^{\circ} \mathrm{C}$ and $\mathrm{pH}$ 7. The control represents $100 \%$ of the protease inhibitor activity under the same condition in the absence of any metal. Data shown are mean $\pm \mathrm{SD}(n=3)$ integrity of protease inhibitors, such as $\mathrm{Mg}^{2+}$ and $\mathrm{Zn}^{2+}$ which maintain the secondary and tertiary structure of cysteine protease inhibitors. However, the side chain carboxylates of aspartate and glutamate amino acids could be involved in bivalent cations binding to metalloproteins causing a decrease in the protease inhibitor activity (Greenwood et al. 2002; Jack et al. 2004).

Effects of divalent metal ions on the purified RfIP1 were determined at $\mathrm{pH} 7$ and $37^{\circ} \mathrm{C}$. Results are given in Fig. 5 by the addition of different concentrations of divalent metal ions to the reaction media (Fig. 5). As one can see from Fig. 5 in contrast to $\mathrm{Cd}^{2+}, \mathrm{Co}^{2+}, \mathrm{Fe}^{2+}$, and $\mathrm{Mn}^{2+}$ which were not able to support protease inhibitor activity and caused a notable inhibition between 38 and $73 \%$ of the residual activity, $\mathrm{Zn}^{2+}$ and $\mathrm{Mg}^{2+}$ ions significantly improved the RfIP1 activity up to $62 \pm 2.8$ and $56 \pm 3.6 \%$, respectively, when compared to the residual activity of control at a concentration of $1 \mathrm{mM}$. Interestingly, the RfIP1 activity was highly enhanced up to $182 \pm 4.6 \%$ at higher concentration $(10 \mathrm{mM})$ of $\mathrm{Hg}^{2+}$, while the presence of $10 \mathrm{Mm} \mathrm{Ca}^{2+}$ was found to promote the remaining RfIP1 activity only up to $15 \pm 2.3 \%$. Bijina et al. found that the addition of $\mathrm{Zn}^{2+}(1 \mathrm{mM})$ and $\mathrm{Hg}^{2+}$ $(10 \mathrm{mM})$ markedly enhanced the activity of the protease inhibitor purified from Moringa oleifera leaves (Bijina et al. 2011). Data obtained in the present study suggested that metal ions bind to the $R$. frangula protease inhibitor and stabilize it spatial conformation. 


\section{Effect of oxidizing and reducing agents and surfactants on the RfIP1 activity}

Surfactants and protease inhibitors are generally combined in cell lysis solutions to maximize membrane protein and other biological materials solubilization and also to inhibit undesirable proteolysis. For this reason, effect of surfactants on $R$. frangula protease inhibitor activity was also checked and data were presented in Table 2. One can see

Table 2 Effects of surfactants and oxidizing and reducing agents on the stability of RfIP1 activity

\begin{tabular}{|c|c|c|}
\hline Detergent components & $\begin{array}{l}\text { Concentration } \\
(\%)\end{array}$ & $\begin{array}{l}\text { Residual activity } \\
(\%)\end{array}$ \\
\hline None & & 100 \\
\hline \multicolumn{3}{|l|}{ Surfactants } \\
\hline Tween-20 & 1 & $85 \pm 2.5$ \\
\hline Tween-80 & 1 & $54 \pm 2.8$ \\
\hline Triton-X100 & 1 & $52 \pm 1.5$ \\
\hline SDS & 1 & $170 \pm 2.5$ \\
\hline NaTDC & 1 & $182 \pm 1.7$ \\
\hline \multicolumn{3}{|l|}{ Oxidizing agents } \\
\hline \multirow[t]{5}{*}{ Hydrogen peroxide $\left(\mathrm{H}_{2} \mathrm{O}_{2}\right)$} & 1 & $70 \pm 4$ \\
\hline & 2 & $58 \pm$ \\
\hline & 3 & $41 \pm 2.6$ \\
\hline & 4 & $32 \pm$ \\
\hline & 5 & $28 \pm 2.5$ \\
\hline \multirow{5}{*}{$\begin{array}{l}\text { Sodium hypochlorite } \\
(\mathrm{NaOCl})\end{array}$} & 1 & $45 \pm 1.6$ \\
\hline & 2 & $29 \pm 2.1$ \\
\hline & 3 & $15 \pm 0.5$ \\
\hline & 4 & $7 \pm 0.2$ \\
\hline & 5 & 0 \\
\hline \multirow{5}{*}{$\begin{array}{l}\text { Dimethyl sulfoxide } \\
\text { (DMSO) }\end{array}$} & 1 & $35 \pm 2.5$ \\
\hline & 2 & $31 \pm 1.4$ \\
\hline & 3 & $24 \pm 0.7$ \\
\hline & 4 & $19 \pm 1$ \\
\hline & 5 & $15 \pm 0.5$ \\
\hline \multicolumn{3}{|l|}{ Reducing agents } \\
\hline \multirow[t]{5}{*}{ Dithiothreitol (DTT) } & 0.2 & $105 \pm 2$ \\
\hline & 0.4 & $114 \pm 1.5$ \\
\hline & 0.6 & $122 \pm 2.1$ \\
\hline & 0.8 & $139 \pm 1.8$ \\
\hline & 1 & $155 \pm 3$ \\
\hline \multirow[t]{5}{*}{$\beta$-Mercaptoethanol ( $\beta \mathrm{ME})$} & 0.2 & $102 \pm 0.8$ \\
\hline & 0.4 & $112 \pm 1.2$ \\
\hline & 0.6 & $129 \pm 2$ \\
\hline & 0.8 & $137 \pm 0.5$ \\
\hline & 1 & $149 \pm 1.9$ \\
\hline
\end{tabular}

Results are the relative protease inhibitor activity expressed as the percentage of the maximum activity recorded without the addition of compound. Data are mean $\pm \mathrm{SD}(n=3)$ that, except NaTDC and SDS, none of the ionic and nonionic surfactants tested activated the purified protease inhibitor. In fact, it was observed that the residual activity of the RfIP1 was promoted by 82 and $70 \%$ compared to control in the presence of NaTDC or SDS, respectively. This finding suggested that SDS and NaTDC could act as stabilizer for the RfIP1 under extreme conditions of $\mathrm{pH}$ or temperature. However, the inhibitor protein lost more than $45 \%$ of its initial activity in the presence of Triton X100 and Tween 80 , while Tween 20 was able to reduce the inhibitory activity of the protease inhibitor by only $25 \%$ compared to the control. These observations could be attributed to a reduction in the hydrophobic interactions.

On the other hand, oxidizing agents checked for their influence on the RfIP1 activity showed that as the concentration of the oxidizing agent tested increased as the protease inhibitor activity decreased. In fact, as we can see in Table 2, the protease inhibitor lost 35 or $72 \%$ in the presence of 1 or $5 \%$ DMSO, respectively, compared to control (without any oxidizing agent). Likewise, the RfIP1 activity was reduced by 30 or $72 \%$, respectively, in the presence of 1 or $5 \% \mathrm{H}_{2} \mathrm{O}_{2}$, while it was completely lost in the presence of only $4 \% \mathrm{NaOCl}$. This reduction could be linked to a possible oxidation of the amino acid methionine at the inhibitor protein reactive site (Johnson and Travis 1979). Furthermore, the effect of two reducing agents on the activity of protease inhibitor was also evaluated, and data were shown in Table 2, and it seems that both DTT and $\beta$-ME could enhance inhibitory activity up to $55 \%$ at $1 \%$ concentration (Table 2). Similar results were reported for the protease inhibitor from M. oleifera (Bijina et al. 2011) which suggested that, in the presence of reducing agents, the functional stability of Kunitz-type protease inhibitors is presumably attributed to the intramolecular disulphide (Kunitz 1947).

\section{Effect of the RfIP1 on proteases with therapeutic importance}

Serine protease inhibitors are well known to modulate protease activities and control multiple critical protease mediated processes, such as fibrinolysis, tissue remodeling and coagulation (Laskowski and Kato 1980) as well as in the development of cancer (Koivunen et al. 1991) and the neurobiology of aging (Higgins et al. 1990). The R. frangula purified protease inhibitor in the present study showed a significant affinity toward the chymotrypsin, thrombin and trypsin which are well known for their therapeutic and pathological importance. Cathepsin B and collagenase also exhibited a good level of inhibition, whereas no significant inhibition was recorded toward elastase (Fig. 6). These finding results corroborate perfectly with those previously obtained by Bijina et al. that demonstrated the highest 
Fig. 6 Inhibitory activity of RfIP1 activity toward different pharmaceutically and commercially important proteases. Data are means of triplicate determinations $\pm \mathrm{SD}$

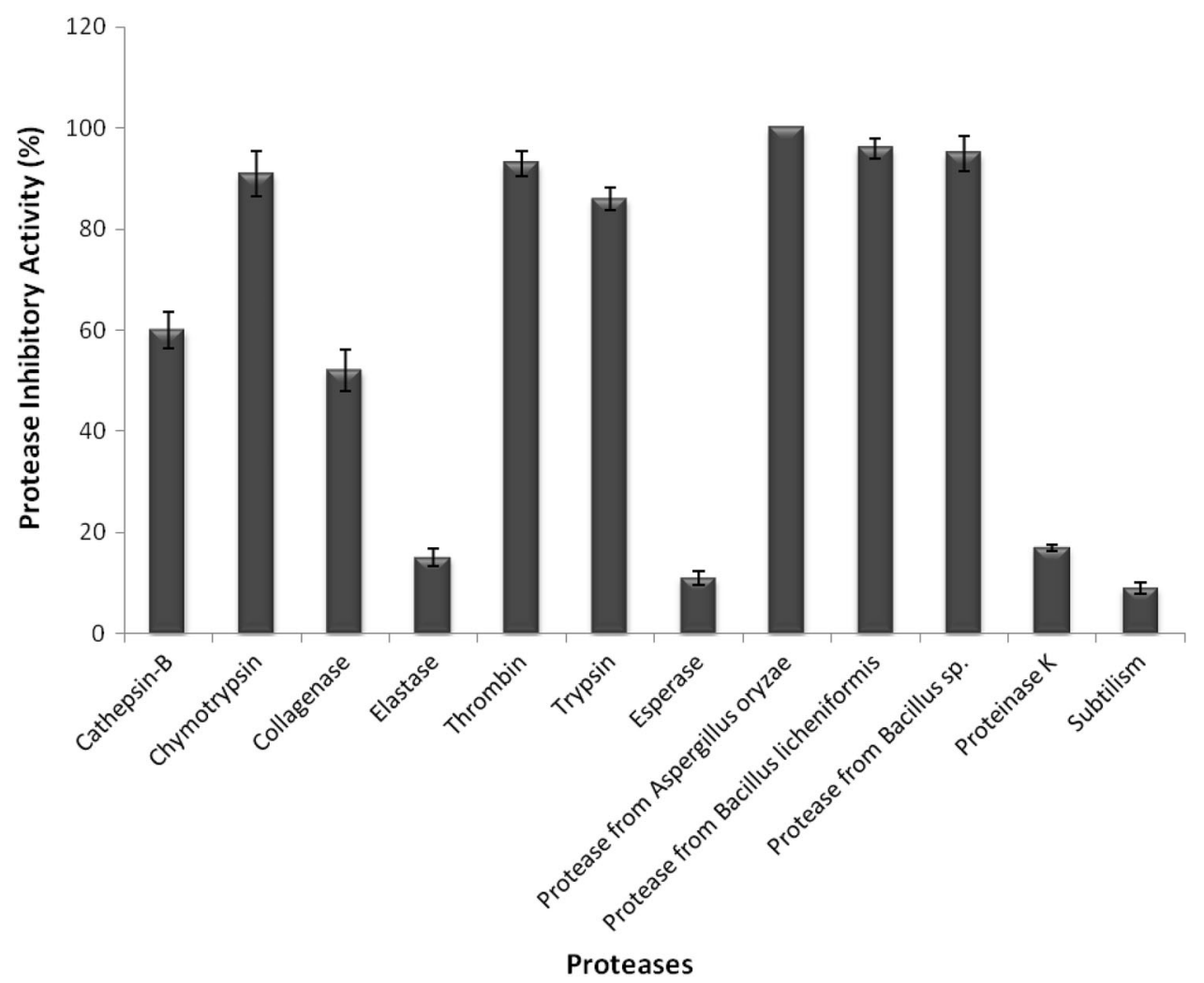

inhibition of Bovine trypsin and chymotrypsin by the $M$. oleifera protease inhibitor and also some serine proteases involved in the blood clotting cascade (Bijina et al. 2011). The recorded high affinity of the purified RfIP1 leaves toward thrombin makes it a potential candidate to use as an anticoagulant agent.

Several reports suggested that cathepsin B is involved in the invasive process of cancer pathology and is also considered as the most virulent protease found in several protozoan diseases, such as Leishmaniasis (Keppler et al. 1985). Keppler et al. demonstrated that cathepsin B is strongly inhibited by cysteine protease inhibitor in the cancer cells suggesting that the inhibitor could play a protective role in the tumor invasion. Mottram et al. suggested that cathepsin L-like and cathepsin B-like, which are involved in virulence and parasitic growth a promising and attractive tool for novel chemotherapy for Leishmaniasis (Mottram et al. 1988). In 2002, Banks et al. have isolated trypsin/chymotrypsin inhibitor with potent antifungal properties from broad bean (Banks et al. 2002). In addition, several studies have demonstrated that cysteine and serine proteases, in particular, reduced fecundity, delayed development, and growth and may also increase mortality (Ryan 1990; Oppert et al. 1993; Annadana et al. 2002; Oppert et al. 2003; Azzouz et al. 2005). Thus, the protease inhibitor isolated from $R$. frangula could be developed for use as a possible drug in pharmaceutical industries and also for the direct application as a biocontrol agent for the protection of plants against phytopathogenic fungi.

\section{Effect of the RfIP1 on some commercially important proteases}

The affinity of purified RfIP1 with six industrially important proteases was also checked. Data presented in Fig. 6 showed clearly that the commercially proteases obtained from Aspergillus oryzae (100\% inhibition), Bacillus sp (95\% \pm 3.5 inhibition), and Bacillus licheniformis (96 $\pm 2 \%$ inhibition) were almost dramatically inhibited by $R$. frangula protease inhibitor. In contrast, a negligible inhibitory effect was recorded against esperase $(11 \pm 1.3 \%$ inhibition), proteinase $\mathrm{K}$ (17 $\pm 0.7 \%$ inhibition), and subtilisin ( $9 \pm 1.2 \%$ inhibition).

It is well established that bacterial and fungal proteases, in particular those derived from Bacillus isolates, have potential for biotechnological applications as additives in different industries, such as pharmaceuticals, leather processing and detergents strains (Abdel-Naby et al. 1998; Mabrouk et al. 1999). Pandhare et al. demonstrated that the thermal stability of an alkaline protease isolated from fungus Conidiobolus macrosporous with prospective use in leather and detergent industries could be improved by a protease inhibitor isolated from actinomycete (Pandhare 
Table 3 Antibacterial properties of the crude extract and the purified protease inhibitor from $R$. frangula leaves against several Grampositive and Gram-negative bacteria

\begin{tabular}{llll}
\hline Bacteria strain & \multicolumn{2}{l}{ Inhibition zone $(\mathrm{mm})$} & IC $_{50}$ \\
\cline { 2 - 4 } & Crude extract & Pure protease inhibitor & \\
\hline Gram+ & $15 \pm 1.8$ & $25 \pm 0.3$ & 2 \\
B. cereus (ATCC 14579) & $16 \pm 0.5$ & $24 \pm 1.2$ & 3 \\
B. subtilis (ATCC 6633) & $13 \pm 0.5$ & $20 \pm 0.5$ & 3 \\
E. faecalis (ATCC 29122) & $15 \pm 1.2$ & $21 \pm 1.1$ & 5 \\
S. epidermidis (ATCC 14990) & $17 \pm 1.6$ & $23 \pm 0.6$ & 4 \\
S. aureus (ATCC 25923) & & & 11 \\
Gram- & - & $11 \pm 1.8$ & 10 \\
E. coli (ATCC 25966) & - & $9 \pm 0.7$ & 13 \\
K. pneumonia (ATCC 700603) & - & $12 \pm 1.2$ & 14 \\
P. aeruginosa (ATCC 27853) & - & $26 \pm 0.8$ & 2 \\
S. enteric (ATCC 43972) & & & \\
Ampicillin & & & \\
\hline
\end{tabular}

The bactericidal effect of the protease inhibitor was assessed by measuring the diameter of inhibition zone $(10 \mu \mathrm{g} / \mathrm{well})$ and the protease inhibitor concentration necessary to kill $50 \%$ of the initial inoculum ( $\left.\mathrm{IC}_{50}\right)$, which was deduced from curves obtained from three independent experiments. Ampicillin was used as the positive reference standard, and acetate buffer was used as the negative control

$(-)$ : insensitivity et al. 2002). Hence, authors suggested that binding of protease inhibitor could prevent the thermal denaturation of detergent proteases. The fact that RfIP1 did not exhibit any significant inhibitory effect against detergent enzymes suggested probable application for $R$. frangula protease inhibitor as stabilizer for improving thermal stability of detergent enzymes.

\section{Antibacterial activity of the purified RfIP1}

Several studies have demonstrated that protease inhibitors suppress the activity of the pathogenic microorganism's protease in addition to the alteration of its membrane permeability, thus suggesting being effective antibacterial agents (Wijaya et al. 2000; Arulpandi and Sangeetha 2012). In this context, the antibacterial activity of $R$. frangula protease inhibitor was evaluated against ten Gram-negative and Gram-positive bacteria. The antibacterial activity on pathogenic strains was determined by measuring the inhibition zone diameter after the inoculation of bacteria with the purified RfIP1 in Luria broth agar media and the determination of the $\mathrm{IC}_{50} \%$ values (Table 3 ). Results presented in Table 3 showed that the purified $R$. frangula protease inhibitor was as effective as ampicillin, the reference standard, and exerted appreciable antibacterial effect against both Gram-positive and Gram-negative bacteria. The highest activity was recorded against both Bacillus $[B . \quad$ Cereus $\quad(26 \pm 0.3 \mathrm{~mm}) ; \quad B . \quad$ subtilis $(25 \pm 1.2 \mathrm{~mm})]$ and Staphylococcus $[S$. aureus
$(24 \pm 1.5 \mathrm{~mm}) ; S$. epidermidis $(23 \pm 0.6 \mathrm{~mm})]$ strains followed by $E$. faecalis $(20 \pm 0.5 \mathrm{~mm})$ and $E$. coli $(15 \pm 1.3 \mathrm{~mm})$, while the least activity was against $K$. pneumonia $(7 \pm 0.5 \mathrm{~mm}), P$. aeruginosa $(9 \pm 1.5 \mathrm{~mm})$ and $S$. enteric $(8 \pm 1.2 \mathrm{~mm})$. However, the crude extract was less efficient against all the tested Gram-positive bacteria when compared to the purified protease inhibitor and had no effect against Gram-negative bacteria used in this study.

The bactericidal effects of the protease inhibitor were also studied by investigating viable $\mathrm{CFU}$ after incubation of $10^{8} \mathrm{CFU} / \mathrm{ml}$ with different amounts of the inhibitor protein for $2 \mathrm{~h}$. A significant reduction of the inoculum was recorded for all tested bacterial strains within $2 \mathrm{~h}$ even at the lowest concentration tested $(10 \mu \mathrm{g} / \mathrm{ml})$ (Table 3). It can also be noted that at the highest concentration of the protease inhibitor $(50 \mu \mathrm{g} / \mathrm{ml})$, over $96 \%$ of the two Bacillus strains and L. monocytogene died after $2 \mathrm{~h}$ (Data not shown). The antibacterial effect of the protease inhibitor was appreciable against E. faecium, $S$. aureus, and $S$. pyogenes, whereas Pseudomonas aeruginosa, Klebsiella pneumonia, and E. coli required higher amounts of the inhibitor protein.

The present data are of great importance, especially in the case of Staphylococcus aureus and Bacillus subtilis, which are resistant against some antibiotics and synthesize various enterotoxins that provoke septicemia and enteritis (Hajji et al. 2010). Arulpandi and Sangeetha (Arulpandi and Sangeetha 2012) purified a protease inhibitor, named 
fistuli, from Cassia fistula leaves and studied its antibacterial activity against $\mathrm{Gram}^{+}$and $\mathrm{Gram}^{-}$bacterial strains. The efficacy of fistuli was found to be comparable to streptomycin sulfate used as the standard drug. The purified protease inhibitor was highly active against $B$. subtilis, E. coli, K. pneumonia, and $S$. aureus. Another trypsin inhibitor that may possess anti-insecticidal and antibacterial properties was isolated and characterized from the seeds of $C$. fistula by Wijaya et al. (Wijaya et al. 2000).

\section{Conclusion}

Based on the results of the purification and the biochemical characterization of RfIP1, we can conclude that the purified protease inhibitor may have potential for the development of effective medicament in pharmaceutical industries against therapeutic serine protease, such as cathepsin B, chymotrypsin, collagenase, thrombin, and trypsin. Furthermore, this protease inhibitor could become a suitable candidate for several biotechnological applications particularly in food industry, and as a biocontrol defense protein for the protection of plants against pathogen infestations. Furthermore, RfIP1 was markedly protected against Gram-positive and, to lesser extent, Gram-negative bacteria thereby proving its contribution to the host defense against serious bacterial infection. Hence, this antibacterial molecule may also be effective as an alternative source of antibiotics against pathogen microbial infections.

Acknowledgements The authors extend their appreciation to the Deanship of Scientific Research at King Saud University for funding the work through the research group project No: RGP-VPP-070.

\section{References}

Abdel-Naby MA, Ismail AS, Ahmed SA, Abdel-Fattah AF (1998) Production and immobilization of alkaline protease from Bacillus mycoides. Bioresour Technol 64:205-210

Ahn JE, Salzman RA, Braunagel SC, Koiwa H, Zhu-Salzman K (2004) Functional roles of specific bruchid protease isoforms in adaptation to a soybean protease inhibitor. Insect Mol Biol 13:649-657

Annadana S, Peters J, Gruden K, Schipper A, Outchkourov NS, Beekwilder MJ, Udayakumar M, Jongsma MA (2002) Effects of cysteine protease inhibitors on oviposition rate of the western flower thrips, Frankliniellaoccidentalis. J Insect Physiol 48:701-706

Arulpandi I, Sangeetha R (2012) Antibacterial activity of fistulin: a protease inhibitor purified from the leaves of Cassia fistula. ISRN Pharm 2012:4

Azzouz H, Cherqui A, Campan EDM, Rahbe Y, Duport G, Jouanin L, Kaiser L, Giordanengo P (2005) Effects of plant protease inhibitors, Oryza cystatin I and soybean Bowman-Birk inhibitor, on the aphid Macrosiphum euphorbiae (Homoptera, Aphididae) and its parasitoid Aphelinus abdominalis (Hymenoptera, Aphelinidae). J Insect Physiol 51:75-86
Banks W, Niehoff M, Brown R, Chen Z, Cleveland T (2002) Transport of an antifungal trypsin inhibitor isolated from corn across the blood-brain barrier. Antimicrob Agents Chemother 46:2633-2635

Barrett AJ (1981) Alpha 2-macroglobulin. Methods Enzymol 80:737-754

Berghe VA, Vlietinck AJ (1991) Screening methods for antibacterial and antiviral agents from higher plants. Methods Plant Biochem $6: 47-68$

Bijina B, Chellappan S, Krishna JG, Basheer SM, Elyas KK, Bahkali AH, Chandrasekaran M (2011) Protease inhibitor from Moringa oleifera with potential for use as therapeutic drug and as seafoodpreservative. Saudi J Biol Sci 18:273-281

Bradford MM (1976) A rapid and sensitive method for the quantification of microgram quantities of proteins utilizing the principle of protein-dye binding. Analy Biochem 72:248-254

Creighton TE, Charles IGJ (1987) Sequences of the genes and polypeptide precursors for two bovine protease inhibitors. Mol Biol 194:11-22

Cyran R (2002) New developments in therapeutic enzyme inhibitors and blockers. BCC Research, Norwalk

De Leo F, Volpicella M, Licciulli F, Liuni S, Gallerani R, Ceci LR (2002) PLANT-PIs: a database for plant protease inhibitors and their genes. Nucleic Acids Res 30:347-348

Ellenreider E, Geronazzo H, Bojarski AB (1980) Thermal inactivation of trypsininhibitors in aqueous extracts of soybeans, peanuts and kidney beans: presenceof substances that accelerate inactivation. Cereal Chem 57:25-26

European Medicines Agency (EMEA) (2007) Evaluation of Medicines for Human Use. London. http://www.ema.europa.eu/docs/ en_GB/document_library/Herbal_-_HMPC_assessment_report/ 2009/12/WC500018613.pdf. Accessed 25 May 2016

Fritz H, Hartwich G, Hoppe EW, Seylers Z (1966) On protease inhibitors. I. Isolation and characterization of trypsin inhibitors from dog pancreas tissue and pancreas secretion. Physiol Chem 345:150-165

Greenwood IA, Leblanc N, Gordienko DV, Large WA (2002) Utilization of Avizyme 1502 in corn-soybean meal diets with and without antibiotics. Eur J. Physiol 443:473-482

Hajji M, Jarraya R, Lassoued I, Masmoudi O, Damak M, Nasri M (2010) GC/MS and LC/MS analysis, and antioxidant and antimicrobial activities of various solvent extracts from Mirabilis jalapa tubers. Process Biochem 45:1486-1493

Hamato N, Koshiba T, Pham TN, Tatsumi Y, Nakamura D, Takano R, Hayashi K, Hong YM, Hara SJ (1995) Trypsin and elastase inhibitors from bitter gourd (Momordicacharantia LINN) seeds: purification, amino acid sequences, and inhibitory activities of four newinhibitors. Biochem 117:432-437

Hänsel R, Sticher O (2007) Pharmakognosie-Phytopharmazie, 8th edn. Springer, Heidelberg, pp 928-930

Hewick RM, Hunkapiller MW, Hood LE, Dreyer WJ (1981) A gas liquid solid phase peptide and protein sequenator. Biol Chem 256:7990-7997

Higgins G, Oyler G, Neve R, Chen K, Gage FH (1990) Altered levels of amyloid protein precursor transcripts in the basal forebrain of behaviorally impaired aged rats. Proc Natl Acad Sci USA 87:3032-3036

Ian MC (2001) Matrix metallo proteinases protocols. In: John MW (ed) Methods in Moleculer Biology. Humana Press Inc, UK, p 392

Imada C (2005) Enzyme inhibitors and other bioactive compounds from marine actinomycetes. Antonie Van Leeuwenhoek 87:59-63

Jack NL, Cate NM, Rishipal RB, Hiba AB (2004) Inhibition of matrix metalloproteinase-I activity by the soybean Bowman-Birk inhibitor. Biotechnol Lett 26:901-905 
Jamal S, Poddar NK, Singh LR, Dar TA, Rishi V, Ahmad F (2009) Relationship between functional activity and protein stability in the presence of all classes of stabilizing osmolytes. FEBS J 276:6024-6032

Jofuku KD, Goldberg RB (1989) Kunitz trypsin inhibitor genes are differentially expressed during the soybean life cycle and in transformed tobacco plants. Plant Cell 1:1079-1093

Johnson S, Pellecchia M (2006) Structure- and fragment-based approaches to protease inhibition. Curr Top Med Chem 6:317-329

Johnson D, Travis J (1979) The oxidative inactivation of human alpha-1-proteinase inhibitor. Further evidence for methionine at the reactive center. J Biol Chem 254:4022-4026

Keppler D, Pagano M, Dalet-Fumeron V, Engler R (1985) Regulation of neoplasm-specific cathepsin B by cysteine-protease inhibitors present in cancerous exudates. CR Acad Sci III 300:471-474

Kim JY, Park SC, Hwang I (2009) Protease inhibitors from plants with antimicrobial activity. Int J Mol Sci 10:2860-2872

Koivunen E, Ristimaki A, Itkonen O, Vuento M, Stenman U (1991) Tumor associated trypsin participates in cancer cell-mediated degradation of extracellular matrix. Cancer Res 51:2107-2112

Kremer D, Kosalec I (2012) Anthraquinone profiles, antioxidant and antimicrobial properties of Frangula rupestris (Scop.) Schur and Frangula alnus Mill. Bark Food Chem 131:1174-1180

Kridric M, Fabian H, Brzin J, Popovic T, Pain RH (2002) Folding, stability and secondary structure of a new cysteine dimeric proteinase inhibitor. Biochem Biophys Res Commun 297:962-967

Kunitz MJ (1947) Crystalline soyabean trypsin inhibitor II. General properties. Gen Physiol 30:291-310

Laemmli UK (1970) Cleavage of structural proteins during the assembly of the head of bacteriophage T4. Nature 227:680-685

Laskowski MJ, Kato I (1980) Protein inhibitors of protienase. Ann Rev Biochem 49:593-626

Lawrence PK, Koundal KR (2002) Plant protease inhibitors in control of phytophagous insects. Electron J Biotechnol 5:93-109

Mabrouk SS, Hashem AM, El-Shayeb NMA, Ismail AS, Abdel-Fattah AF (1999) Optimization of alkaline protease productivity by Bacillus licheniformis ATCC 21415. Bioresour Technol 69:155-159

Macedo MLR, Freire MGM, Cabrini EC, Toyama MH, Novello JC, Marangoni SA (2003) Trypsin inhibitor from Peltophorum dubium seeds active against pest protease and its effect on the survival of Anagasta kuehniella. Biochim Biophys Acta 1621:170-182

Males Z, Kremer D (2010) Quantitative analysis of glucofrangulins and phenolic compounds in Croatian Rhamnus and Frangula species. Acta Biol Crac Ser Bot 52:108-113

Manojlovic NT, Solujic S, Sukdolak S, Milosev M (2005) Antifungal activity of Rubia tinctorum, Rhamnus frangula and Caloplaca cerina. Fitoterapia 76(2):244-246
Mello GC, Oliva MLV, Sumikava JT, Machado OLT, Marangoni S, Novello JC (2002) Purification and characterization of a new trypsin inhibitor from Dimorphandramollis seeds. J Protein Chem 20:625-632

Meulenbroek EM, Thomassen EA, Pouvreau L (2012) Structure of apost-translationally processed heterodimeric double-headed Kunitz-type serine protease inhibitor from potato. Acta Crystallogr D Biol Crystallogr 68:794-799

Mosolov V, Valueva T (2005) Proteinase inhibitors and their function in plants. A review. Appl Biochem Microbiol 41:227-246

Mottram JC, Brooks DR, Coomps GH (1988) Roles of cysteine proteinases of Trypanosomes and Leishmania in host-parasite interactions. Curr Opin Microbiol 1:455-460

Okazaki K, Yamada H, Imoto T (1985) A convenient protein substrate for the determination of protease specificity: reduced and S-3-(trimethylated amino)propylated lysozyme. Anal Biochem 149:516-520

Oppert B, Morgan TD, Culbertson C, Kramer KJ (1993) Dietary mixtures of cysteine and serine proteinase inhibitors exhibit synergistic toxicity toward the red flour beetle, Tribolium castaneum. Comp Biochem Physiol 105:379-385

Oppert B, Morgan TD, Hartzer K, Lenarcic B, Galesa K, Brzin J, Turk V, Yoza K, Ohtsubo K, Kramer KJ (2003) Effects of proteinase inhibitors on digestive proteinases and growth of the red flour beetle, Tribolium castaneum (Herbst) (Coleoptera: Tenebrionidae). Comp Biochem Physiol Part C 134:481-490

Pandhare J, Zog K, Deshpande VV (2002) Differential stabilities of alkaline protease inhibitors from actinomycetes: effect of various additives on thermostability. Bioresour Technol 84:165-169

Pichare MM, Kachole MS (1996) Protease inhibitors of Pigeon pea (Cajanuscajan) and its wild derivatives. Physiol Plant 98:845-851

Reppond KD, Babbitt JK (1993) Protease inhibitors affect physical properties of arrowtoothflounder and walleye pollacksurimi. J Food Sci 58:96-98

Robert AC (2005) Evaluation of enzyme inhibitors in drug discovery. A guide for medicinal chemists and pharmacologists. Wiley, Germany

Ryan CA (1990) Protease inhibitors in plants: genes for improving defenses against insects and pathogens. Ann Rev Phytopathol 28:425-449

Ştef DS, Gergen I, Traşcă TI, Monica Hărmănescu SL, Ramona B, Hegheduş M (2009) Total antioxidant and radical scavenging capacities for different medicinal herbs. Rom Biotechnol Lett 14(5):4704-4709

Wijaya R, Neumann GM, Condron R, Hughes AB, Polya GM (2000) Defense proteins from seed of Cassia fistula include a lipid transfer protein homologue and a protease inhibitory plant defensin. Plant Sci 159:243-255 